\title{
Sustainable flood memories, informal knowledge and the development of community resilience to future flood risk
}

\author{
L. J. McEwen ${ }^{1}$, F. Krause ${ }^{2}$, O. Jones ${ }^{1} \&$ J. Garde Hansen ${ }^{2}$ \\ ${ }^{1}$ University of the West of England, UK \\ ${ }^{2}$ University of Gloucestershire, UK
}

\begin{abstract}
The UK policy change from 'flood defence' to 'flood risk management' in the 1990s has involved shifts to more distributed flood risk management responsibilities. This poses questions about roles of floodplain residents in community-led adaptation planning for changing flood risk, and how these roles can be supported/strengthened. Research evidence emphasises importance of informal/local/lay knowledge, 'watery sense of place', flood memories and shared flood heritage, in how communities prepare for, and recover from, floods. This paper outlines initial research outcomes from an interdisciplinary UK Economic and Social Research Council-funded research project that proposes the concept of 'sustainable flood memory' in the context of effective flood risk management. This is conceived as an approach to memory work that is community focused, archival, integrating individual and collective experiences, involving inter- and intra-generational communication, and strategies for its future. The project aims to increase understanding of how flood memories provide a platform for developing informal knowledge, so creating social learning opportunities in communities that can increase their adaptive capacities and flood resilience. It explores: how communities remember and archive flood experiences; how local flood knowledge is materialised, assimilated and protected; the role of catastrophic floods (e.g. July 2007, River Severn, UK) in building 'community' memory and flood risk knowledge; and whether informal knowledge is tacit or otherwise, if and how it is learned, and whether it can be
\end{abstract}


transmitted, developed, revitalised and returned in settings where it is lost or lacking.

Keywords: adaptive capacity community engagement, flood risk, informal knowledge, resilience, sustainable flood memory.

\section{Introduction}

This paper outlines UK Economic and Social Research Council funded research (ESRC) that is investigating the importance of sustainable flood memory, with its associated 'watery sense of place', shared flood heritage, folk memories of flooding, local flood knowledge, community flood awareness and opportunities for social learning (see ESRC Flood Memories website/blog [1]). How do these different elements interact to influence the propensity for local action to increase community resilience to future flooding? The interdisciplinary research connects geography, environment, heritage, media, and cultural and memory studies. The research is evaluating the extent to which communities that have a history of past flood events are more resilient to future flood events than communities with no previous history of flooding, or no shared memories of flooding. This paper starts by setting the research contexts, proposes the concept of sustainable flood memory, outlines aims and methods, and identifies emerging themes from initial project results.

\subsection{Recent UK flood events, policy response background and local communities}

The policy change from 'flood defence' to 'flood risk management' (FRM) after the 1998 and 2000 floods (rivers Avon, Severn, UK; Tunstall et al. [2]; Johnson et al. [3]) involved a shift to more distributed responsibilities for UK flood risk management. This is set in context of climate change scenarios that predict increased risk of specific types of flooding (UKCIP [4]), and major questions over sustainability of hard engineering defence solutions. The catastrophic floods (Marsh and Hannaford [5]) and management crises in Hull and the Severn catchment in July 2007 proved to be one of the greatest civil emergencies that the UK has faced, with loss of life, houses/businesses devastated, and strategic transport, power and water infrastructures threatened, damaged and disabled. In the aftermath, a whole range of agencies and tiers of government have reviewed procedures and planning in FRM from local to national levels (Cabinet Office [6]; DEFRA [7]). Several imperatives (e.g. need for adaptive capabilities after floods; community lead adaptation planning) have emphasised research needs to establish how floodplain groups can be made less vulnerable, and more sustainable and resilient (Tobin [8]).Therefore, investigating the relationships between sustainable flood memory, local knowledge, and how individuals/communities deal with risk and effective community level planning in developing local resilience, is important, whilst recognising that the concept of 'community' is itself contested. This involves exploring new and different perspectives on the sociology of risk, drawing on different literatures around 
changing meanings of disasters (e.g. Furedi [9]), with crises as catalysts of change and cultural memory.

\subsection{Distributed flood risk management}

Distributed FRM involves all stakeholders taking some degree of responsibility for their own protection (e.g. by take-up of flood insurance, or flood resilience/resistance measures to their property; CIRIA [10]). If individuals are not aware of flood risk or how to respond in flood events then they will not prepare or deal effectively in emergencies. Even if they do perceive risk, research indicates that individuals may still not act rationally to protect themselves against future flooding (Baker [11]). Clark and Priest's [12] research on public awareness of flood risk, drawing on theories of 'reasoned action' and 'behaviour change', challenges notions that public information can alter public behaviour in clearly defined or predictable ways.

\subsection{Local/lay/informal knowledge}

It is increasingly recognised that local knowledge is articulated in various ways as lay, traditional and indigenous knowledge (hereafter local knowledge), nested within notions of common wisdom, that have implications for mapping knowledge and the redistribution of expertise (Whatmore [13]; Lane et al. [14]). The 2007 floods challenged the role of formal FRM and 'expert' knowledge in how to manage fluvial floods (Cabinet Office [6]). One emergent element in the review process is that local flood knowledge and associated local senses/values of place are key elements in developing flood knowledge to build future community resilience (McEwen and Jones, [15]). Local knowledge at individual and community levels is increasingly considered important through the Disaster Response Spiral - in preparation and during floods, and in adaptive capabilities and post-flood learnings (Dufty [16]; McEwen [17]).

\subsection{Community level planning}

The increased focus on the 'local' is step-changing the roles of community groups in community-lead adaptation planning, and increasing the role of Local Resilience Forums. Local community action groups formed to campaign around flood risk issues on specific stretches of local water courses perceived themselves to be unheard by official FRM organisations prior to the 2007 events. The same groups are now being co-opted by expert agencies (e.g. water supply companies; environmental regulator) into planning and governance structures (McEwen and Jones [15]). Similarly, Parish Councils, and even concerned/ informed/ active individual citizens, are being supported and encouraged to become part of the resilience/planning structures. Their monitoring of water courses and drainage systems at the most detailed, local level provides local information that can link into wider 'expert' knowledge systems. This local knowledge is often intimately connected with memories of, and emotional responses to, past flood events which persist in a number of ways. 


\subsection{Loss of community knowledge}

This incorporation of local communities and their knowledge into flood resilience planning needs to take into account the changing nature of UK communities (Coates [18]). These cannot be assumed to be homogenous or contiguous in rural or urban areas. Rather they are likely to be plural, multifaceted, fluid and made up of groups with a disparity of resources. Vulnerable groupings (by age, socio-economic class, ethnicity, disability) may be particularly exposed to changing flood risk, and may also be those least likely to develop a sense of place and community memories of past flood events which help them deal with future flooding. There is anecdotal evidence that traditional community flood resilience has reduced or broken down in communities with transient or intermittent membership. This poses important questions as to how flood memories develop, what local flood knowledge comprises, and how it is developed and shared. This parallels how climate change is constructed differently by individuals and communities, in contrast to climatologists (Hulme et al. [19]).

\section{The project}

It is therefore urgent and timely to explore flood memories and how these provide the platform for developing character and role of local knowledge for personal and community resilience. This requires research that explores: (a) how communities remember and archive flood experiences; (b) how local flood knowledge is materialised, assimilated and protected; (c) the role of catastrophic floods in building community, community identity, and community knowledge of flood risk, in conjunction with more frequent, moderate floods; (d) whether informal knowledge is tacit or otherwise, if and how it is learned, with key factors in the social learning process; and (e) whether informal knowledge can be transmitted, developed, revitalised and returned in settings where for various reasons it is lost or lacking. The research is critically evaluating the extent to which, and in what ways, sustainable flood memories contribute to local flood knowledge, building community resilience in the face of changing flood risk and actual events. To achieve this, the research is comparatively studying three communities in the lower Severn valley, UK, which have different histories, forms and levels of past flood experience, and different degrees of community development.

\subsection{Extreme floods and flood histories}

The impact of the July 2007 floods in the UK highlighted the need for community capacity building for effective FRM. These floods were caused by sustained, high intensity rainfall over a wide area, combining fluvial, pluvial (rainfall) and groundwater flooding, with low annual percentage probabilities of occurrence $(<0.5$ in some catchments; Marsh and Hannaford [5]). The floods formed part of a 'flood rich' period on the middle to lower Severn, with severe 
floods in April 1998 and November/December 2000. In contrast, a 'flood poor' period occurred in 1970s and 1980s, with a proceeding flood cluster in the 1960s (McEwen [17]). The largest $20^{\text {th }}$ century flood occurred in March 1947 currently within living memory of some older floodplain residents.

\subsection{Sustainable memories, senses of place and heritage}

In the past few decades, memory studies have flourished and academic work has drawn upon the sociological and psychological approaches to personal (Bartlett [20]), collective (Halbwachs [21]), social (Fentress and Wickham [22]), and cultural (Sturken [23]) memory. This research proposes the concept of sustainable flood memory, which can be conceived as an approach to memory work that is community focused, archival, integrating individual/personal and collective/community experiences, involving inter- (vertical) and intragenerational (horizontal) communication and strategies for its future. The research aims to discover what factors link memory and local knowledge, and how these connect and disconnect during and after flood events. It explores how unravelling these factors can help understand processes of community or informal social learning that might be supported/enhanced in flood governance by agencies concerned with FRM at local level. These insights can then be used as a means to strengthen community resilience to future flood events in terms of actual flood impact and risk.

The evidence base for sustainable flood memory is taken to be the narratives, histories and folk memories of previous flood events and their impacts that are embedded in local communities and culture. This in turn, we suspect, can lead to what is a 'watery sense of place' - that is living with water and the risks it brings become part of collective understandings of place characteristics, distinctiveness and identity. While flooding is not exactly welcomed, living with floods and flood risk in terms of knowledge, expectation and resilience becomes part of peoples' individual, family and community identity. Some idea of this kind of understanding of place can found in Sutherland and Nicholson's [24] book Wetland: Life in the Somerset Levels, where living with flooding is depicted as a key marker of place identity.

\section{Research methods}

The lower Severn Valley was one of the worst affected areas in July 2007 floods; and where members of the research team already had extensive knowledge, previous research experience and contacts. The three communities studied comprise: (a) an 'established' community which has a significant history of episodic extreme floods, regular experience of flooding, and corresponding flood memories (Setting 1); (b) a 'newer' community which has no previous history of flooding (built after previous extreme floods) but which was flooded in July 2007 (Setting 2); and (c) one floodplain district with a past history of extreme flooding including recent experience in 2007, but with significant transient or intermittent occupation of residents, and thus less chance of developing long 
term community cultures/knowledge (Setting 3). In addition, a rural/ urban contrast was built into the research design.

The project is developing the model of a stakeholder competency group (SCG; cf. Langström, et al. [25]) as an integral part of the research process. Its principle is that key stakeholders can input to the research process, inform the analysis of results, and advise on dissemination processes to maximise research value and impact. The SCG comprises community flood action groups, the environmental regulator, local government, Parish and Community Councils (lowest tier of UK government), rural community development councils, National Flood Forum (national self-help group for those affected by flooding), insurance industry, and local archives/museums. Thirty residents are being interviewed in each case-study area, using a snowballing technique to identify interviewees. Several themes were considered in the semi-structured interviews:

- Background of interviewee

- 2007 floods: What happened?

- 2007 floods: How did you react?

- Previous flooding

- Memory and resilience

- Recording the flood

- Sharing stories, images and other records

- Remembering and forgetting

- Maintaining/developing memories.

\section{Emerging research themes}

Initial analysis of the interviews indicates that a large volume of personal flood memories and interest in floods exist in the three settings. Memories of floods cover a spectrum of experiences including revitalised community spirit, and diverse emotional responses, with awe, fear, excitement, grief and challenge all represented. The following synthesis briefly explores some emergent themes, with illustrative quotes.

\subsection{Memory as process}

Memory can be conceived as a vertical process as much as a defined body of knowledge experienced horizontally. This is reflected widely in the memory studies literature, from Halbwach's [21] classic analyses to current studies (e.g. Erll and Nünning [26]; Olick and Robbins [27]). A key part of that process is encouraging people to remember and pass down their knowledge, which they may already do in private settings. Creating opportunities for communities to remember helps develop memories; critical here is establishing the sites and frames of sustainable flood memory.

She: 'Some new people had moved into the street. We said, it would be nice for the new people to get to know the people who already lived here.'

Interviewer: 'And in these occasions, do floods come on as a subject?' She: 'Yeah, sometimes.' 
He: 'Of course it does. You talk about it, you know. And then, that's the time when the bad things come out as well as the good things.' (female, 63 years, and male, 62 years, Setting 3).

When the memory is experienced horizontally as a body of knowledge in a public setting, tensions can exist in promoting local flood memory in wellestablished communities.

'We have a church flower festival here every two years. [...] Our friend next door, he's the Chairman of the Flood Prevention Committee, and [...] he produced [...] photographs on big boards and wanted to put them in the churchyard [...] when the last flower festival was on, but he was turned down by the committee [...] he was allowed a small portion in a tent but he wanted to let everybody see, all the visitors, because they get up to 3,000 to 4,000 because it's over 3 days, [...] he wanted everybody to see what the situation had been like..'. (male; 73 years, Setting 1).

\subsection{Diverse ways of memorialising/ materialising floods}

Methods of materialising, memorialising and visualising floods vary widely. Flood marking of maximum 2007 flood levels against physical or known points of reference has occurred at several locations that have community resonance on churches, public houses, teashops, garages. Flood materialisation occurs in newspaper cuttings; photography/film making; oral history/storytelling; and the emerging use of new technologies including social networking sites. Such materialisation varies in the extent to which it is official/unofficial, verifiable, and at personal or community levels. Physical locations for flood materialisation can be in individual houses, and collated in official and informal archives. Flood materialisation can occur in the everyday - through the resistance/resilience measures implemented post-flood in the home.

'We had a look outside her front door, which is always blocked with a flood barrier (that she is able to step over, though. Nevertheless, she seems to usually use her back entrance).' (interviewer notes - woman, 82 years, Setting 3).

\subsection{Childhood memories of 'learning to live with floods'}

Some interviewees, with longer residency, in remembering the 2007 floods, referred to childhood memories of living through floods in 1947 and the 1960s, and 'awareness/knowing what you can and cannot do' in flood water. These memories embody changing attitudes to living with water, and willingness to take risk. There was a strong view that people need to be aware of the possibility of flooding, and its dangers as part of a 'watery sense of place'.

'I've always been brought up around flooding. As a child, we used to walk the floods. We've done it on Christmas Day, to walk to the pub at Lower Lode across the embankments, the flood barriers. There was water rushing; it was quite deep. All holding hands linked, and mum had wrapped scarves around our hands. We were walking along and [name] was tied to the dog, my little sister. [...] He's a big dog, a big lurcher cross greyhound, so he's a big powerful dog. 
[...] And then we all went to the pub for a drink. Well, they did; we all just played in the floods.' (male, 34 years, Setting 1)

'And then way back, ever since I was a youngster I can remember the floods coming in. And it was a regular thing that in February you always looked out to see, you'd look across the meadow as we called it. It hadn't been filled in [with the landfill site] then. And because the river would overflow and you keep your eye on it, you see oh it's coming up, coming up, get the furniture up, get the carpets up.' (female, 74 years, Setting 3 ).

Such childhood memories demonstrate a watery sense of place, with insights into past coping strategies and common wisdom that can be brought to present and future flooding. Opportunities exist for inter-generational learning around resilience strategies in past communities.

\subsection{Memories of family/community response}

Flood memories also revolved around the impact of floods on family, along with their reactions and responses to the situation and loss, and during flooding, the support from neighbours and friends.

'When it was about three o'clock in the morning and there was left myself, my mum and dad, [name] who works for us, and he'd stayed to help. [name] who works for us, and he'd stayed to help... All the customers had gone. [name]'s wife was sat upon the bar. [...] Dad was behind the bar up to his waist in water. We all had drinks in our hands, and dad went, "that's it, **** to it. What's happened has happened." And then [name] started singing 'always look on the bright side of life' by Monty Python, while we were covered up to our waist! And we all just stood there - it's on video somewhere, just wish I could find it. [...]That will be something that I'll remember for the rest of my life'. (male, 34 years, Setting 1)

\subsection{How to develop flood memories}

A key area of research exploration is how to develop flood memories in settings where they are lacking or lost. Some respondents suggested the importance of bringing up 'living with flooding' as an issue regularly, independently of actual flood events, e.g. through schools in the curriculum (e.g. a flood week); festivals linked more broadly to water heritage ("Water Festival"); exhibitions (at houses; local museums/ heritage centres, or in public spaces), and presentations/ fora that encourage community groups to share images, stories, videos.

I said to them a little while ago, I had lots of pictures and would anybody be interested, and they said yes. And of course this is a building where people retire, so we have lots of people moving in and out. We have had lots of newcomers who wouldn't have a clue, so of course they were very keen to come and have a look, and they were astonished'. (female, 75 years, Setting 3)

Other proposals included the use of sculpture to remember washland areas as a key element of community identity. Some of these suggested community engagement methods have been used elsewhere to promote 'watery sense of place' (e.g. Shrewsbury's Water Festival). 


\subsection{Active remembering}

Active remembering can occur through 'associations' or nuclei of people (e.g. community flood action groups) brought together during the 2007 floods (Hemming [28]). Flood Action Groups are frequently initiated and mobilised after extreme floods (e.g. Severn and Avon Combined Flood Action Group [29]). Rehearsal and reinforcement of flood memory can occur through their on-going campaigning activities to secure official inputs to their flood protection. This keeps flood memory high in the consciousness of both the association and other community members.

\subsection{Active forgetting}

Some people prefer not to remember the floods, because they associate them with painful/traumatic memories. Local knowledge can lack tuning (e.g. that intense rainfall always leads to extreme floods).

'I think you've got to actually try and forget them cause they were terrifying. And if you try... If you think too much about it then you... I mean, obviously for two or three years after those floods every bit of rain, every bit of flooding terrified some people, absolutely terrified them. They thought that this was all going to happen again.' (female, 76 years, Setting 2)

Others have 'moved on', with the 2007 flooding perceived as 'old news', unwilling to discuss their experiences. 'Active forgetting' poses questions about the characteristics of people who do not want to remember, and the implications for their adaptive capabilities and post-flood learnings, particularly when they are key players in communities.

What messages are conveyed with new or upgraded flood alleviation works? 'It will never happen again' or 'this is a flood risk area?' An engineering intervention can only be effective up to design limits - the well known 'levee effect' (Tobin [30]) - but can lead to the belief that residual risk is removed.

'And then after that in the 1970s we put up the new defences and it was working extremely well. People got more confident and the Council said okay, and some of the semi-derelict houses were bought and completely rebuilt and that sort of thing. So we were quite confident really. ' (male, 75 years, Setting 1).

\subsection{Flood memories as catalysts for action}

Flood memory can act as a catalyst for individual and community action, through the implementation of individual resistance/ resilience measures or through local campaigning for 'official' assistance. For example:

'In my day, 40 years ago, we wanted to improve the flood banks then, and we had a sub-committee within the village that increased the height of the banks, with completely our own efforts really. [...] We were already existing with a pretty good set-up really, and then after the 2007 flood it was realised by the village that the flood defences wanted making much higher and much stronger and so this sub-committee was formed of five of us I think, and we then started making plans to get grants.' (male, 75 years, Setting 1). 


\subsection{Relationships with other stakeholders in FRM}

In some urban floodplain groups, memories of the 2007 floods were articulated in terms of widespread disillusionment with, and distrust of, formal bodies (environmental regulator, local government). In others, flood memories embodied a more positive experience of working with official organisations to mitigate risk. At the same time, institutional memory in organisations with a stake in FRM can decay rapidly, with restructuring, staff changes/losses, and functions outsourced. The changing membership of our SCG reflects such personnel changes during the ESRC project.

\section{Conclusions}

The emerging evidence poses questions for resilience planning and increasing the adaptive capabilities and post-flood learnings of floodplain groups. Topdown flood risk management can assume and enhance the dependency of groups and individuals living on floodplains; distributed FRM requires empowered and well-informed communities. Our research has uncovered considerable local learning resources and data that support the concept of sustainable flood memory. This can be practiced vertically (between generations and over time) as much as horizontally (in the moment of flooding). It is the former memory process that is worth pursuing publicly.

Creating strategies for vertical community memories of flooding has potential to produce social learning between groups and over time, so informing approaches to community flood education. Horizontal community memories show up the diverse ways that different individuals materialise flood memory during a flood event in a discreet moment in time (oral recordings, artwork, videos, photographs, social networking, diaries, news reports). It is the connection of the horizontal and vertical axes to provide opportunities for intergenerational learning of past coping strategies that could be developed as a means of increasing community resilience in a flood risk context.

Active forgetting is only possible if community memory remains on the horizontal axis and memories are only passed down privately. Likewise, institutional memories need to understand how community memory functions and how best to engage local knowledge to increase the adaptive capacity/ postflood learnings of floodplain groups. Contrasts can be made between the character and longevity of individual/ community and institutional memory, with implications for how organisations work with community to develop flood memory.

The next stages of the project combine participant observation at meetings, in depth focus groups with community, and interviews with key institutional stakeholders. Outcomes from the project will include two action packs for community and organisational stakeholders, co-produced with the stakeholder competency group, outlining how sustainable flood memory can be enhanced and developed as a means of increasing community resilience. 


\section{Acknowledgement}

This research is funded by the UK Economic and Social Research Council.

\section{References}

[1] ESRC Sustainable flood memories. Available at: www.glos.ac.uk/flood memories; floodmemories.wordpress.com [accessed on $24^{\text {th }}$ February 2012].

[2] Tunstall, S.M., Johnson, C.L. and Penning-Rowsell, E.C. Flood hazard management in England and Wales: from land drainage to flood risk management, Proceedings - World Congress on Natural Disaster Mitigation. The Institution of Engineers (India) - WFEO, India 2, 447-454, 2004.

[3] Johnson, C. L., Tunstall, S. M., and Penning-Rowsell, E. C. Floods as catalysts for policy change: historical lessons from England and Wales. International Journal of Water Resources Development, 21, 561-575, 2005.

[4] United Kingdom Climatic Impacts Programme (UKCIP). Available at www.ukcip.gov.uk [accessed on $1^{\text {st }}$ May 2009].

[5] Marsh, T. J. and Hannaford, J. The summer 2007 floods in England and Wales - a hydrological appraisal. Centre for Ecology and Hydrology, Wallingford, UK, 2007.

[6] Cabinet Office The Pitt Review: Lessons learned from the 2007 floods http://www.cabinetoffice.gov.uk/thepittreview.aspx, 2008.

[7] DEFRA Government Response to Pitt Review (Dec 2008).

[8] Tobin, G.A. Sustainability and Community Resilience: The Holy Grail of Hazards Planning? Environmental Hazards: Human and Policy Dimensions, Global Environmental Change, Part B. 1, 13-25, 1999.

[9] Furedi, F. The changing meaning of disaster. Area 39.4, 482-489, 2007.

[10] Construction Industry Research and Information Association (CIRIA) Available at: http://www.ciria.org [accessed on $12^{\text {th }}$ December 2009]

[11] Baker, V. Flood hazard science, policy, and values: A pragmatist stance. Technology in Society 29, 161-168, 2007.

[12] Clark, M. J. and Priest, S. J. Public awareness of flood risk: the role of the Environment Agency flood map. ESRC End of Award Report, RES-000-221710. Swindon: ESRC, 2008.

[13] Whatmore, S. J. Mapping knowledge controversies: science, democracy and the redistribution of expertise. Progress in Human Geography 33, 587598, 2009.

[14] Lane S. N., Odoni N., Landström Whatmore S. J., Ward N. and Bradley S. Doing flood risk science differently: an experiment in radical scientific method. Transactions of the Institute of British Geographers 36, 15-36, 2011. 
[15] McEwen, L. J. and Jones, O. Building local/lay flood knowledge into community flood resilience planning after the July 2007 floods, Gloucestershire, UK. Hydrology Research, Special Issue (in press).

[16] Dufty, N. A new approach to flood education. The Australian Journal of Emergency Management 23, 4-8, 2008.

[17] McEwen, L. J. Approaches to Community Flood Science Engagement: the Lower River Severn catchment, UK as Case-study. International Journal of Science in Society 2, 159-179, 2011.

[18] Coates, T. The Conscious Community: belonging, identities and networks in local communities' flood response. Unpublished $\mathrm{PhD}$, Middlesex University, UK, 2010.

[19] Hulme, M., Dessai, S., Lorenzoni, I. and Nelson, D. R. Unstable climates: exploring the statistical and social constructions of 'normal' climate Geoforum 40, 197-206, 2009.

[20] Bartlett, F.C. Remembering: An Experimental and Social Study, Cambridge University Press, Cambridge, 1932.

[21] Halbwachs, M. On Collective Memory. Translated and edited by Lewis A. Coser. University of Chicago Press, Chicago, [1925] 1992.

[22] Fentress, J. and Wickham, C. Social Memory Blackwell, Oxford, 1992.

[23] Sturken, M. Tangled Memories: The Vietnam War, the Aids Epidemic, and the Politics of Remembering. Berkeley: University of California Press, 1997.

[24] Sutherland, P. and Nicholson, A. Wetland: Life in the Somerset Levels, Mermaid Books, Williamsburg, Virginia, 1986.

[25] Langström, C., Whatmore, S. J., Lane, S. N., Odoni, N. A., Ward, N. and Bradley, S. Co-producing flood risk knowledge: redistributing expertise in critical 'participatory modelling'. Environment and Planning A 43, 16171633, 2011.

[26] Erll, A., Nünning, A. (eds.), and S. Young, A Companion to Cultural Memory Studies. Germany: De Gruyter, Germany, 2008.

[27] Olick, J. K. and Robins, J. Social Memory Studies: From "Collective Memory" to the Historical Sociology of Mnemonic Practices. Annual Review of Sociology 24, 105-140, 1998.

[28] Hemming, H. Together: how small groups achieve big things. John Murray, London, 2011.

[29] Severn and Avon Combined Flood Group Building on the floodplain is misguided (a definitive proof of evidence). Unpublished report, 2008.

[30] Tobin, G. A. The levee love affair: a stormy relationship. JAWRA Journal of American Water Resources 21, 359-367, 1995. 